8 Raine A. The SPQ - a scale for the assessment of schizotypal personality based on DSM-III-R criteria. Schizophr Bull 1991; 17: 555-64.

9 Eysenck SBG, Eysenck HJ, Barrett P. A revised version of the psychoticism scale. Pers Individ Dif 1985; 6: 21-9.

10 Newman CW, Weinstein BE, Jacobson GP, Hug GA. The hearing handicap inventory for adults - psychometric adequacy and audiometric correlates. Ear Hear 1990; 11: 430-3.

11 Hymans DG. Curve Expert 1.4. Hixton, 2009 (http://www.curveexpert.net/ curveexpert-basic/).

12 Lee KH, Egleston PN, Brown WH, Gregory AN, Barker AT, Woodruff PWR. The role of the cerebellum in subsecond time perception: Evidence from repetitive transcranial magnetic stimulation. J Cognitive Neurosci 2007; 19 147-57.

13 Spence C, Shore DI, Klein RM. Multisensory prior entry. J Exp Psychol Gen 2001; 130: 799-832.

14 Stone JV, Hunkin NM, Porrill J, Wood R, Keeler V, Beanland M, et al. When is now? Perception of simultaneity. Proc $R$ SOC Lond B Biol 2001; 268: 31-8.

15 Lee KH, Dixon JK, Spence SA, Woodruff PWR. Time perception dysfunction in psychometric schizotypy. Pers Individ Dif 2006; 40: 1363-73.

16 Busey T, Craig J, Clark C, Humes L. Age-related changes in visual temporal order judgement performance. Vision Res 2010; 50: 1628-40.

17 Woodruff $\mathrm{P}$, Wright I, Bullmore $\mathrm{E}$, Brammer $\mathrm{M}$, Howard R, Williams $\mathrm{S}$, et al. Auditory hallucinations and the temporal cortical response to speech in schizophrenia: a functional magnetic resonance imaging study. Am $J$ Psychiatry 1997; 157: 1676-82.
18 Ford JM, Roach BJ, Jorgensen KW, Turner JA, Brown GG, Notestine R, et al. Tuning in to the voices: a multisite fMRI study of auditory hallucinations. Schizophr Bull 2009; 35: 58-66.

19 Hunter M, Woodruff P. Characteristics of functional hallucinations. Lett Am J Psychiatry 2004; 161: 923.

20 Hoffman RE, Varanko M, Gilmore J, Mishara AL. Experiential features used by patients with schizophrenia to differentiate 'voices' from ordinary verbal thought. Psychol Med 2008; 38: 1167-76.

21 Nayani T, David A. The auditory hallucination: a phenomenological study. Psychol Med 1996; 26: 177-89.

22 Alais D, Carlile S. Synchronizing to real events: subjective audiovisual alignment scales with perceived auditory depth and speed of sound. Proc Natl Acad Sci USA 2005; 102: 2244-7.

23 Zampini M, Shore DI, Spence C. Audiovisual prior entry. Neurosci Lett 2005; 381: 217-22.

24 Gooding DC, Matts CW, Rollman EA. Sustained attention deficits in relation to psychometrically identified schizotypy: evaluating a potential endophenotypic marker. Schizophrenia Res 2006; 82: 27-37.

25 Alba-Ferrara L, de Erausquin G, Hirnstein M, Weis S, Hausmann M. Emotional prosody modulates attention in schizophrenia patients with hallucinations. Front Hum Neurosci 2013; 7: 59.

26 Hatashita-Wong M, Siverstein SM. Coping with voices: selective attention training for persistant auditory hallucinations in treatment refractory schizophrenia. Psychiatry 2003; 66: 255-61.

27 Valmaggia LR, Bouman TK, Schuurman L. Attention training with auditory hallucinations: a case study. Cognit Behav Pract 2007; 14: 127-33. psychiatry in pictures

\section{High Royds Hospital, Menston, Ilkley} Richard Mindham

High Royds Hospital was the third of four large hospitals built by the West Riding of Yorkshire County Council to accommodate 'pauper lunatics'. The hospital was designed by the county engineer J. Vickers Edwards, work began in 1884 and the hospital was opened in 1888. Pavilions were arranged in an echelon formation with the administrative block, which included a tower and clock, at the centre and the service area behind, the whole linked by covered corridors. There were wards designated for the care of patients with epilepsy and other special groups. Subsequently there were many additions to the hospital which included an infirmary, long-stay wards detached from the hospital and a 'neurosis unit' built in the modern style in 1938.

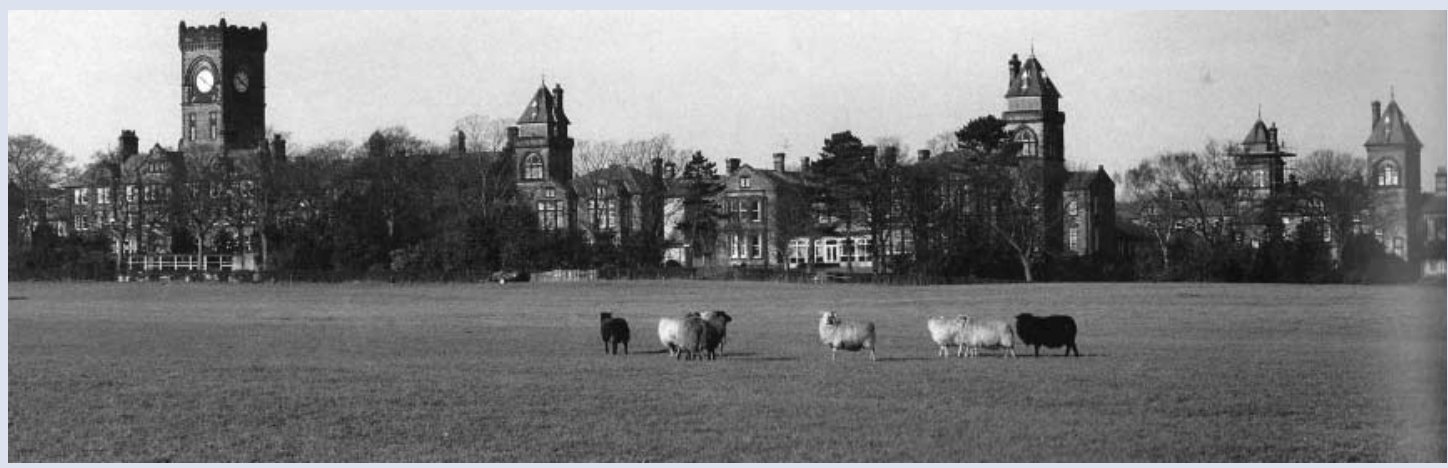

High Royds Hospital photographed by Norman Hodgson, 1995.

The hospital was set in an elevated site about 10 miles from both Leeds and Bradford, surrounded by its own extensive gardens and farm, with high moors on all sides. The hospital was built in a subdued Arts and Crafts style in sandstone from local quarries, with a splendid roof of Westmorland slate with elaborate lead work and finials. Internally, the woodwork was of oak and pitchpine, the walls were glazed to dado height and the floors were of marble mosaic. The hospital was served by its own water supply, railway line and burial ground. Facing south overlooking its grounds the hospital gave an impression of considerable grandeur.

In 1958 the hospital achieved a population of 2500 patients; thereafter it declined until its closure in 2003. It is a listed building grade $\|$ and is in a green belt. The site is being redeveloped for residential use. 